\title{
A Play Of Three Suitors: A Neglected Middle Dutch Version of the "Entrapped Suitors" Story (ATU 1730)
}

Ben Parsons and Bas Jongenelen

\begin{abstract}
The wide diffusion of the "Entrapped Suitors" story-type has often been observed: examples are found in a remarkable number of literatures, ranging from English, French and Greek in the west, to Persian, Arabic and Kashmiri in the east. However, a text of this type that is often overlooked is the Middle Dutch play Een Speel Van Drie Minners ('A Play Of Three Suitors'). This is despite the fact that it represents a highly idiosyncratic variation on the story, as it replaces the central moral with something more scabrous. We offer here a comprehensive discussion of this singular text and its narrative form, with an English verse-translation appended.
\end{abstract}

The purpose of the present article is to call attention to an unusual variant of story-type ATU 1730 (Uther 2004). often overlooked in surveys of the narrative form. This is the Dutch farce Een speel van drie minners, de coster, de pape ende de jonckere - "A Play of Three Suitors: The Sexton, the Priest and the Squire" (Mak 1950, 1-15). The play belongs to the robust tradition of early modern comic drama in the Netherlands. [1] It survives in a single unsigned copy, preserved in a manuscript now held at the Royal Library of Brussels. Internal evidence, such as its playful and light-hearted treatment of the clergy - which directly contrasts with the harshness of post-Reformation anticlericalism - suggest that the play was written shortly before the 1520s. [2] The piece is not only remarkable for the comparative neglect it has received, but also for the new meanings it pushes on to its topos. These often stand in direct conflict to other, more conventional accounts.

The wide circulation of story-type ATU 1730, or "the Entrapped Suitors," is well attested. Several literatures around the world contain at least one version of the story. A measure of the tale's popularity is its appearance in virtually all of the great story-collections of the Middle Ages. The tale of a woman exposing, imprisoning or otherwise humiliating multiple unwanted 
suitors is a staple of medieval miscellanies and frame-narratives. Amongst the earliest of these is the eleventh-century Kathasaritsagara by the Kashmiri poet Somadeva. Here the young woman Upakosa is accosted by three court officials while performing her ablutions. Annoyed by their interruptions, she arranges for the men to visit her at her home, whereupon she strips each naked, ostensibly in preparation for a bath, before forcing him to hide in a basket, which is then sealed and conveyed to the king (Somadeva 1997, 14-9). The Arabian Nights' Entertainments also incorporates a comparable story. In this version the woman's lover or husband has been arrested: appealing to the city-governor, the cadi, the vizier and the king for his release, she only finds herself repeatedly propositioned. Exasperated, she invites each man in turn to her lodging, and stows them in a different compartment of a large cupboard. The carpenter hired to make the cupboard is similarly imprisoned. The five men are only released after the woman's neighbours hear their shouts (Dawood 1973, 106-10).

European collections also make heavy use of the topos. Story CLXXXVIII of the Gesta Romanorum, sometimes given the title "De carpentario et camisia," preserves another version. This concerns a carpenter's wife "in the reign of Gallus," who is solicited by three soldiers, whom she imprisons "and feeds on bread and water," only releasing them at the intervention of the emperor (Dick 1890, 99-102). Some versions of The Seven Sages of Rome also include clear variations on the tale. Possibly the earliest form of the Sagescycle, the Indian Sinbadnameh, contains a story similar to that preserved in the Arabian Nights (Wright 1849, lxvi). The Dutch Die seven wijse mannen (1479) also contains a curious variant, in which the woman's husband instructs her to seduce three knights, and demand a gift of money from each. The suitors arrive at the couple's home one after the other, where the woman takes their money, and the husband butchers each man in turn (Botermans 1898). Giovanni Boccaccio gives yet another version of the story-type in the Decameron (c.1350). In Boccaccio's telling one Madonna Francesca attracts the unwanted attentions of two Florentine exiles, Rinuccio and Alessandro. To 
deter her pursuers, she "induces the one to enter a tomb and pose as a corpse, and the other to go in and fetch him out": both flee when they are challenged by the city's night watchmen (Boccaccio 1972, 682-7).

Outside such collections, the same plot is also used in several texts which are full works in their own right. One example is the thirteenth-century fabliau Constant $d u$ Hamel. This describes how the wife of a "paisant" is approached by a provost, a forester and a priest, each of whom she strips naked, stashes in a barrel of feathers, and casts into the street (Rostaing 1953). A pair of fifteenth-century English works provide two further analogues: The Wright's Chaste Wife (c.1462), supposedly "seyde" by one "Adam of Cobsam," and The Lady Prioress and Her Three Suitors (c.1475), a work which is discussed more fully below (Salisbury 2002, 10-8). Further versions of the story have also been documented in Greek, Arabic and Indian folklore. [3] When similar episodes in longer texts are also considered, such as Merlin's imprisonment "vnder a grete stone" by the lady Nimue in Malory's Morte Darthur (c.1470), it becomes apparent that the story-type is firmly embedded in the bloodstream of medieval literature (Malory 1996, 89). In fact, such is the prevalence of the story that it outlives the Middle Ages itself. In 1728 the Scottish poet Allan Ramsey used the tale as the basis for his ballad “The Monk and The Miller's Wife," a piece which has been praised as "Ramsay's most distinguished narrative poem" from its first publication (Crawford, Hewitt and Law 1987, 16-20; Maclaine 1985, 112). In the Low Countries too there are several postmedieval versions. No less than five sixteenth- and seventeenth-century plays make use of the same plot: Job Gommersz's Klucht van de bedrogen minnaars (1565), J. Franssoon's Giertje Wouters (1623), Jan van Breen's Bedrooge jalouzy (1659), J. Pluimer's De bedrooge vryers (1679), and the anonymous Klucht van Fytje (1700) (Worp 1903, vol. 1, 454-5). Even later than this the story remains popular in the Low Countries. Jurjen van der Kooi notes two further examples from the nineteenth century: an anonymous "street-ballad" titled "De uitgezaagde minnaar," and Waling Dykstra's Frisian version "De hingelmatte" (Van der Kooi 1997, 387-90). 
In terms of their general moral outlook, the versions of the story so far mentioned are all extremely similar. Each displays a tendency to commend the central female character, and through her to acclaim women in general. In the texts women are credited with the power to identify threats to the given social order, and to eliminate these dangers. In most versions the woman defends her vows to her husband, or even her husband himself: this pattern is followed in the Gesta Romanorum, the Arabian Nights, the Sinbadnameh and the Wright's Chaste Wife. In each of these cases, the woman rebuffs a direct attempt to transgress or undermine existing social relations, either in the form of her marriage, or the standing of her husband in his community. Other redactions, particularly Constant $d u$ Hamel and the version in the Kathasarisagara, extend this still further, giving the woman the power to expose corruption within the social order at large. Somadeva's Upakosa, for example, renovates the community as she defends her sexual integrity, laying bare the dishonesty of three court officials. Even seemingly anomalous versions, such as Boccaccio's tale of Madonna Francesca, do not travel far beyond this basic model. The Decameron states that Francesca is punishing "the daring presumption of the lovers," putting down their harmful and excessive social aspiration (Boccaccio 1972, 688). The story not only portrays women as intelligent, resourceful and inventive, but asserts their ability to preserve both their own integrity and that of the wider community. It grants women the power and the judgment to correct any disturbance or disruption to the true order of things, even without male assistance. In short, as Barbara Hanawalt stresses, the core of the tale displays firm feminist sympathies $(1998,89)$.

The version which takes this tendency to the greatest extreme is the text most closely related to Een Speel, the Middle English Lady Prioress and Her Three Suitors. [4] This poem of two hundred and fifty lines, which is doubtfully attributed to John Lydgate in its one surviving manuscript, is typical of English fabliaux, using "trickery to put a stop to illicit behaviour rather than to further it" (Furrow 1989, 13). The text owes its substance to 
Boccaccio, although places greater emphasis on the corrective power of the central character. Firstly, it makes the woman more respectable, not only turning her into the leader of a convent community, but describing her as nobly born, "a lordes dowter." Secondly, while the Decameron story relies on an agency outside the woman's control, in the form of the city watch, the Lady Prioress makes clear that the woman alone is responsible for chastising her pursuers. It involves three suitors, a "young knyght," "a parson of a paryche," and "a burges of a borrow," who are given interlocking tasks by the prioress: the first must lie in a coffin overnight to be deemed worthy of the woman's love; the second is sent to bury this "ded corse" in secret, to "say his dorge and masse, and laye him in his grave"; the third is dressed in a "develles garment" and sent to interrupt the burial (Furrow 1985, 15 and 28). The lovers therefore terrify each other: the knight in the coffin begins to panic as he is being buried, the parson is frightened by the intrusion of the devil, and the merchant is startled when the "corse" springs to life and runs out of the churchyard. In this text, the woman singlehandedly punishes these offenders. She does not draw on any separate force to put her plan into operation, but retains sole authority over the events.

Moreover, the Lady Prioress even permits the woman to preach openly on social duty. In her dealings with her wooers, the prioress often weaves subtle moralisations into her speech. She quietly reminds two suitors of their obligations even as she seems to praise them: the knight is hailed as "ower lord, ower patron, and ower precedent," while the parson is told "we send for you, ouer worshype for to save." At the end of the poem, the prioress even reasserts her own commitment to Christ, issuing the pointed statement, "had I never lover yet that ever dyed good dethe" (Furrow 1985, 28-30). As John Hines comments, "the prioress...consistently and piously respects conventional standards of decency" $(1993,209)$. The poem forcefully spells out the central moral of its story-type, emphatically championing the ability of women to defend social frameworks, and celebrating their innate cleverness and honesty in the process. 
The Dutch Een speel van drie minners, however, directly subverts these ideas, breaking sharply with the position running through most earlier versions of the narrative. In fact, it could almost be said that the play amounts to an antifeminist revision of the story. In most respects the Speel closely follows the Lady Prioress. It retains most of the distinctive features of the English poem: it also features three lovers from different estates (although substitutes the merchant for a coster or "sexton") and focuses on a task which takes place in a graveyard, in which one lover pretends to be a corpse, one pretends to be a devil, and the other attempts to move the "body." It also, unlike the Boccaccio version, leaves the suitors to frighten each other, rather than allowing a third party to intervene. Although the play may not be directly derived from the English poem-its minimal use of explanation suggests that the story was already well-known to the Dutch-speaking audience, presumably from another Dutch source - it is closely related to the Lady Prioress in structure.

Yet despite its resemblance to the English work the Speel is far less sympathetic in its portrayal of women. From the first it adds a new element to the story: it draws on the misogynous commonplace that women tempt men into "ruin" and humiliation (Bloch 1991, 14-15). The opening and closing speeches allude to the stories of Aristotle and Virgil being outwitted by women. First occurring in Henri d'Andeli's Lai d'Arioste (c.1250), tales of how these wise men were "by a womans cauylacon/ Browt to iniquyte and to mych wo" are found throughout medieval Europe (Nolan 1998, 88; Wright $1847,66)$. The wijf of the Speel is herself much closer to the women of these stories than she is to Upakosa or the pious Prioress. She is seemingly motivated by little more than spite. Rather than finding herself pestered by her suitors, she seems to have actively sought their attentions. The play opens with her boasting of her beauty and cunning: she gloats that she "sets many sighing" and has "snared suitors three" (ic ben zeker zeer hertelic ghemint...Daer isser drie, die mij vrihen). She does not even expose the suitors to public ridicule, or parade them before a figure of authority, as do the women in the 
most other versions. In the Speel, the suitors' degradation is staged for her amusement alone, not as a means of securing official or communal rebuke. The woman in the Speel does not defer to any higher authority, and does not embody any moral position. She is more a vindictive deceiver. Rather than defending the social order against interference, she exploits and encourages disruption for her own enjoyment.

Nonetheless, it would not be quite accurate to regard the text as unflinchingly misogynous. While the play certainly introduces antifeminist material, it does not develop this into a coherent attack on women. Rather than condemning the woman's behaviour or character, the Speel seems to revel in her cruelty. The action of the play aligns the woman and the audience: they, like her, are observers of the men's indignities, and are invited to take delight in their abasement. The audience is not placed in opposition to the woman, but made to stand with her. Nor is the woman punished for her trickery. At the end of piece there is no revenge or recompense for the suitors. Once the Speel's woman has initiated her plot, she is able to retire to safety. Even the statement of antifeminist conceits at the end of the piece, which translates its events into the general truth "all women are sly" (vrauwen...daer groote subtijlheijt), is highly ambivalent. The context in which this pronouncement is made undercuts it. Firstly, it is uttered by the sexton, who as a commoner lacks the political authority of the squire and the spiritual authority of the priest: secondly, all three men have been portrayed as nothing but gullible idiots, whose lusts draw them into a blatant trap. Like the comparable tirade in the English Gawain and the Green Knight, this "outburst against women" is made to fall flat (Morgan 2002). The play's revision of the "Entrapped Suitors" topos ultimately seems more amoral than strictly antifeminist. The story-type is stripped of any moral content rather than furnished with a new, anti-female message.

It is also worth noting that this new accent is taken in more aggressive directions by later storytellers in the Netherlands. The Speel's revisions of the story-type are not confined to this one text alone. Its antifeminist tone, no 
matter how slight it may prove on closer inspection, paves the way for more sustained attacks against women in later Dutch versions of the story. Particularly important is a Flemish folktale first recorded in the early nineteenth century, although with apparent roots in the mid sixteenth (Wolf 1851, 11). This is one of several anecdotes to feature the "Lange Wapper," a malicious shape-shifting trickster said to live in the river Scheldt at Antwerp. In this account of the "Entrapped Suitors" story, the Wapper disguises himself as a "licentious" woman of the city. Once he has assumed this form, he meets with four of the woman's lovers, and sends them to the local graveyard, wearing the same disguises as the lovers of Een Speel and the Lady Prioress. However, in this version all but one of the men die of fright. This catastrophe in turn drives the woman to "put an end to her life" out of shame (Thorpe 1852, 217-8). The story thus directs its punitive conclusion against the woman herself: at its climax the woman is penalised for her promiscuity, rather than extolled for her modesty or fidelity. This version strays furthest from a conventional telling of the ATU1730 story-type. It reverses the standard moral resonance of the topos, turning the woman from an agent to an object of punishment. Although Een Speel is by no means as militant in its misogyny, it does open the way for such strident antifeminism, by stripping its own wijf of her conventional moral authority. It may be said that the play is situated midway between the honourable Lady Prioress and the "lascivious woman" of the Wapper story. It initiates the movement from praising the woman with many suitors, to upbraiding her as a whore. In sum, Een Speel stands as a bridge between the earlier philogynous texts and the later, antifeminist version. In terms of the story-type as a whole, its importance is twofold: not only does it alter the central significance of the story, but it instigates a new application of the story-type in Dutch folklore. Owing to these factors, the play deserves consideration.

\section{Appendix}


A Play of Three Suitors: The Sexton, The Priest and the Squire. A Verse Translation [5]

Dramatis Personae:

The WOMAN

The SEXTON

The PRIEST

The SQUIRE

WOMAN: If I so choose I may well declare

To myself each day, "Arise, maiden fair":

I would be in no danger of lying,

For certainly I set many sighing

5

Among the youths, whose hearts madly stir.

I shall dress in high heels and fine fur,

Even if pipers care little for me.

I have already snared suitors three:

They will come soon, of that have no doubt.

10

I will give them something to sigh about.

Old Virgil, Aristotle the wise,

Didn't suffer even half the surprise

That these poor dolts are due to receive.

Aha! The first arrives, I perceive:

15

Now will I pass through my dwelling.

You'll see trickery far excelling

Any ever seen or heard before.

Here he is now, of that I am sure:

I'll wait at the window of my upper floor.

20 SEXTON: Lord God, what bliss may you impart,

Greater than she, to whom I am sworn?

She alone is sought by my heart.

She must bring relief to this man forlorn.

Hey, I say, hey! My sweet darling fawn,

Are you asleep? Speak to me my dear!

WOMAN: Who is there?

SEXTON: It is I, come over here!

It is nine o' clock - and so, as I vowed,

Here I stand.

WOMAN: Ssh! Don't speak so loud:

Think of the neighbours. Are you alone?

30 SEXTON: No-one is with me, small or full-grown.

I wouldn't dare to bring another here:

Of malice and gossip I go in fear.

I come alone, as you can plainly see.

O my sweet love, if you don't comfort me,

I will die tonight, you may be assured. 
WOMAN: Ha! You lie!

SEXTON: No, by the might of the Lord!

Alas! Why would you say such a thing?

If I wasn't lovesick, pained, adoring,

Then this cold winter I would not brave

40

To see you. Would anyone else behave

In this way? I must say I think not!

Earlier this year I stood on this spot

Till I froze, till I couldn't lift my feet

From the ground: and now I entreat

45

You to let me in, and come to you!

WOMAN: Do you love me?

SEXTON: Assuredly I do:

I want you more than I want to live.

WOMAN: Do you swear to this?

SEXTON: $\quad Y e s:$ I will give

Anything I can afford to lose.

50 WOMAN: If you want to collect your proper dues

There is a trial you must undertake:

Take up this coffin for my sake,

And carry it quickly to the churchyard.

Once there clamber in, all fear discard,

And wind this sheet about you. Is that clear?

Whatever you see, whatever you hear,

Inside the coffin you must stay.

SEXTON: O flower of womanhood, right away

I will jump in that box. Hand it to me.

60 WOMAN: That's the spirit. Success I guarantee.

Best of luck to you. Now be on your way.

SEXTON: I will do it, exactly as you say,

For if I lie inside and bite my tongue

My love will be mine before very long.

65

This is excellent! An end to my plight!

Once the clock has tolled out midnight

What my mistress demands, I will enact.

WOMAN: Did you ever hear of a man so cracked?

Can so much folly in one fool reside?

$70 \quad$ Here comes our priest. Time for me to hide.

He sees me as a thing beyond compare.

PRIEST: Hey, I say hey!

WOMAN: Who is that out there?

My lord, is that you?

PRIEST:

Yes, my darling sweet.

Before anyone sees me in the street,

WOMAN: What time is it? 
PRIEST:

Ten.

WOMAN:

What? Already so late?

PRIEST: What of it, my love? Let me scale your stair.

WOMAN: Eventually. But first you must swear

To help me out before tonight is through.

80 PRIEST: As you please.

WOMAN: It will be good for you.

PRIEST: Tell me, sweetness, what is your command?

WOMAN: Take this here bedsheet in your hand:

You will find a coffin at the churchyard;

You must sit on this, no matter how hard

85 It might be. Then crack the nuts I have here.

Even if some phantom should appear

Don't be afraid, but keep up your task.

PRIEST: Yes, blessed child. I will do as you ask.

Then will you share your bed with me?

90 WOMAN: Once all is done.

PRIEST: That fills me with glee.

How long should I sit there in my sheet?

WOMAN: Until midnight.

PRIEST: He who longs for the sweet

Must accept the sour. Pass those nuts here.

WOMAN: Good man! Here they are.

PRIEST: $\quad$ Well thrown, my dear.

95 I won't be alone this time tomorrow.

God guard me from further sorrow.

This deed I do is one most daring.

If the spirits come, they won't be sparing:

Even if I were steel, I would be slain.

100 Well, I see the coffin, clear and plain.

I will sit here and crack throughout the night,

Under this bedsheet. From further plight

God must keep me, and save me from fear.

Ah, that was a hard shell!

SEXTON:

What do I hear?

105

PRIEST: What's that under my behind?

Dead bones rattling! Am I losing my mind?

Cry mercy!

The dead man-he is chattering away!

Veni creator domine!

Great Magnificat, from first to last verse!

110 SEXTON: Let me out!

PRIEST: $\quad$ My fortune is in reverse:

The corpse wants to escape from underneath

Me. I must hold him in.

SEXTON:

I cannot breathe. 
PRIEST: $\quad$ Of all my bad days, this is uppermost:

You will smother me-have a care, ghost!

WOMAN: A sweating blood, such is my distress.

WOMAN: A better play no man could witness,

Neither here nor there. Look what I have done.

Through my tricks two people are undone:

The priest, the sexton-long may they thrive!

120

And soon I know a third will arrive.

He is a squire - hear what I proclaim -

He too will be caught up in my game.

Here he comes now, yet another fool.

SQUIRE: O image of wonder, o noble jewel,

125 The one whom my heart has selected,

Towards whom my love is directed,

Above all others everywhere.

Hey, I say hey!

WOMAN: Who is that out there?

SQUIRE: It is I, as very well you know.

130 WOMAN: What time is it now?

SQUIRE: Eleven or so.

I am yours, my sweet: believe all I say.

WOMAN: I believe no-one.

SQUIRE: I'm in disarray,

Waiting to catch this beauty I behold.

WOMAN: That will not happen.

SQUIRE: $\quad$ For a hill of gold

135 I would not injure your honour or pride.

WOMAN: Do you love me?

SQUIRE: Sure. Are you satisfied?

Now let me in. It will be worth your while.

WOMAN: Are you willing to undergo a trial?

Will you for me a challenge complete

140

To get near my bed?

SQUIRE: In a heartbeat.

I will head to Hell, if you decree it

I will go there gladly.

WOMAN: $\quad$ Then so be it.

Shut up now. Take this devil-costume.

SQUIRE: $\quad$ Part of my task, am I to presume?

145 WOMAN: To put it bluntly, you must wear this suit, And drag this chain through the streets. Your route

Must end at the graveyard.

SQUIRE: I'll do it, I swear.

But what will I do once I am there?

WOMAN: I will tell you. In that yard you must stay

150 And search for a coffin. Then straightaway, 
Without any pause, that box you must bring

To me at my house before the morning.

SQUIRE: Count on me.

WOMAN: $\quad$ Go with speed and diligence

And carry it here, with all its contents.

155

SQUIRE: I will fetch it, my love - complete, entire.

How do I look in my new attire?

WOMAN: Horrible.

SQUIRE: Well, be sure you are awake.

That coffin from the churchyard I shall take:

I am a bold man, and I would not care

160

If Satan himself were waiting there.

But while I walk I will speak no more.

I'm at the graveyard. What's that before

My eyes? Some figure I now apprehend.

Each hair on my head is standing on end.

165 PRIEST: What's this I see, by every prayer I've prayed?

A demon! I was never more afraid!

Have mercy!

SEXTON: $\quad$ The Devil comes. World, farewell!

I am doomed: I am bound for Hell.

PRIEST: What shall I do? Gone is all my cheer.

170 The dead are speaking, the Devil is near,

And my soul is now forever lost:

Never was my heart so beaten and tossed.

SQUIRE: It is a ghost - I can see it stirring.

My heart thumps, my vision is blurring.

175 PRIEST: The Devil speaks.

SEXTON: Is he heading this way?

I must leave, before my mind flits away!

SQUIRE: Can a prize ever be good or right,

Won in a graveyard in the dead of night?

PRIEST: The Devil will destroy everything:

180 My knees shake, my teeth are chattering.

SEXTON: I wish I could change into a bird:

But I dare not move, after all I've heard.

SQUIRE: If I rattle my chains, would that be wise?

I could shoo him away with fearsome cries,

185

Booing, baaing, with a moan and a wheeze,

Like Lucifer rising up from Hades.

Tru, hou, ha, hai!

PRIEST: What will become of me?

I will lose my mind if I do not flee!

SQUIRE: Praise be to Heaven's Queen! It has vanished, That revenant from my sight is banished.

And now my mission is back on track: 
I will take up that coffin on my back.

Muscles, do not fail me. God, that's a weight:

I can barely lift this wretched crate.

195 SEXTON: Fear of perdition has made me bolder:

Devil, remove me from your shoulder!

SQUIRE: What is that sound? From my task I now baulk:

Help me, God - the corpse has started to talk!

SEXTON: The Devil will break my neck, I am sure.

200

He intends to drop me. Oh, please no more!

I wish to God that I was free and clear,

But alas the Devil is the boss here.

Never have I experienced such woe,

To my sweet mistress I will now go.

205

Out of the box I climb. Now a spectre

Stands before her house! Divine protector,

This ordeal has made me ill to the core:

I need to hold the one I adore.

SQUIRE: In my life I never felt so weak

$210 \quad$ As when that carcass started to speak.

But now I see he has run away -

I'll take up the coffin and be on my way.

PRIEST: $\quad$ Old Nick returns: again I'm afraid;

My mind is overwhelmed; my nerves are frayed.

215 SEXTON: What shall I do?

PRIEST: $\quad$ Flight is what I choose:

I'm already doomed - I've nothing to lose.

SQUIRE: Both dead men are here! Oh cursed day!

I'm tempted to throw this coffin away

And make good my escape.

WOMAN: Hold it, you three!

220 I mean the lot of you: listen to me.

PRIEST: How will listening help against this threat?

The Devil is here! Hide me with you, pet!

SQUIRE: I'm no devil.

SEXTON: Oh? If you're not from down

Below, who are you?

SQUIRE: I live in this town,

225 And I'm human.

PRIEST: $\quad$ Me too: I eat and drink,

I am not a ghost, despite what you think.

SEXTON: Neither am I.

SQUIRE: Tell me your names, at least.

SEXTON: I am the sexton.

PRIEST: And I am the priest.

SQUIRE: And I am a squire, with lands over there.

230 SEXTON: By all that's good, this is an odd affair. 
PRIEST: I almost died.

SQUIRE: I was frozen with fright,

It's a miracle that I didn't go mad.

SEXTON: Why did you do all this?

SQUIRE: A woman had

Me do it. In my desire, to my shame,

I could not resist.

SEXTON: $\quad$ My case is the same:

The love of a woman caused my disgrace.

PRIEST: That is true for me too.

SQUIRE: The truth we now face:

240

Each of us has been made to look a fool

By a woman.

SEXTON: Indeed, love's misrule

Caught us all up in a woman's lie.

I tell you now that all women are sly:

All the wise men throughout all the ages

Were born of women; and still these sages

$245 \quad$ Were deceived by women in some way.

We need not blush when we think of this day,

Since women have always caused men to fall.

Farewell, and may God's grace keep us all.

Explicit.

\section{Notes}

[1] For examples of this literature, see Brill 1899; Pleij 1983 ; Hüsken, Ramakers and Schaars, 1992-8....

E.J. Brill, ed. Veelderhande geneuchlijcke dichten, tafelspelen ende refereynen. Leiden: Brill, 1899; Herman Pleij, ed. Een nyeuwe clucht boeck. Muiderburg: Dick Coutinho, 1983; W.N.M. Hüsken, B.A.M. Ramakers and F.A.M. Schaars, eds. Trou moet blijcken. bronnenuitgave van de boeken der Haarlemse rederijkerskamer de Pellicanisten, 8 vols. Assen: Quarto, 1992-8: 6; Bas Jongenelen and Ben Parsons, "A Famous and Most Miraculous Prophesy," Journal of American Folklore 120 (2007).

[2] See for instance Jan Van der Noodt, A Theatre for Voluptuous Worldlings, trans. Theodor Roest and Edmund Spenser, ed. L.S. Friedland. New York: 
Scholar's Facsimiles and Reprints, 1936; B.H. Erné en L.M. van Dis, eds. De

Gentse Spelen van 1539. The Hague: Martinus Nijhoff, 1982; Gary Waite, Reformers on Stage: Popular Drama and Religious Propaganda in the Low Countries of Charles V. Toronto: University of Toronto Press, 2000: 101-164.

[3] See Marilena Papachristophorou, 'The Arabian Nights in Greece: A Comparative Survey of Greek Oral Tradition', Fabula 45 (2004): 311-29; Hasan M. El-Shamy, Types of the Folktale in the Arab World: A Demographically Oriented Tale-type Index. Bloomington: Indiana University Press, 2004: 923-4; W.A. Clouston, Popular Tales and Fictions: their migrations and transformations, 2 vols. Edinburgh: William Blackwood, 1887: 2:436-52.

[4] On the text see Thomas D. Cooke, Peter Whiteford and Nancy Mohr McKinley, "XXIV: Tales," in Manual of the Writings in Middle English, 10501500, ed. by Albert Hartung, 11 vols. New Haven: Connecticut Academy of Arts and Sciences, 1967-2005. 9:3169; Seth Lerer, “British Library MS Harley 78 and The Manuscripts of John Shirley," Notes and Queries 235 (1990): 400403.

[5] Our translation, based on Mak 1950.

\section{References Cited}

Botermans, Antonie Johannes, ed. Die seven wijse mannen van romen. Haarlem: Bohn, 1898.

Bloch, R. Howard. Medieval Misogyny and the Invention of Western Romantic Love Chicago: University of Chicago Press, 1991.

Boccaccio, Giovanni. The Decameron, trans. G.H. McWilliam. Harmondsworth: Penguin, 1972.

Brill ...

Crawford, Thomas, David Hewitt and Alexander Law, eds. Longer Scottish Poems, 1630-1850. Edinburgh: Scottish Academic Press, 1987. 
Dawood, N.J, ed. and trans. The Thousand and One Nights. Harmondsworth: Penguin, 1973.

Dick, Wilhelm, ed. Die Gesta Romanorum Nach der Innsbrucker Handschrift vom Jahre 1342. Erlangen and Leipzig: Georg Boehme, 1890.

Hanawalt, Barbara A. 'Of Good and Ill Repute': Gender and Social Control in Medieval England. Oxford: Oxford University Press, 1998.

Furrow, Melissa, ed. Ten Comic Poems. New York and London: Garland, 1985.

Furrow, Melissa. 'Middle English Fabliaux and Modern Myth', English Literary History 56 (1989): 13.

Hines, John. The Fabliau in English. Harlow: Longman, 1993.

MacLaine, Allan H. Allan Ramsay Boston: Twayne Publishers, 1985.

Mak, J.J., ed. Vier excellente cluchten, Klassieke Galerij 46. Antwerp: De Nederlandsche Boekhandel, 1950, 1-15.

Malory, Thomas. Le Morte Darthur. Ware: Wordsworth, 1996.

Morgan, Gerald. 'Medieval Misogyny and Gawain's Outburst Against Women in Sir Gawain and the Green Knight', Modern Language Review 97 (2002): 265-78.

Nolan, Barbara, 'Promiscuous Fictions: Medieval Bawdy Tales and Their Textual Liaisons', in The Body and the Soul in Medieval Literature: The J.A.W. Bennett Memorial Lectures, ed. Piero Boitani and Anna Torti. 79-106. Oxford: Boydell and Brewer, 1998.

Rostaing, Charles, ed. Constant du Hamel, Fabliau. Edition critique avec commentaire et glossaire, ed. Charles Rostaing. Aix-en-Provence: Annales de la Faculté des Lettres, 1953.

Salisbury, Eve, ed. The Trials and Joys of Marriage. Kalamazoo: Medieval Institute Publications, 2002.

Somadeva. Tales from the Kathasaitsagara, trans. and ed. Arshia Sattar. Harmondsworth: Penguin, 1997.

Uther, Hans-Jörg. The Types of International Folktales. Parts I-III, Helsinki, 2004. 
Van der Kooi, Jurjen. 'De Vrijers in De Kast', in Van Aladdin tot Zwaan kleef aan: lexicon van sprookjes: ontstaan, ontwikkeling, variaties, ed. A. J. Dekker, Theo Meder and Jurjen van der Kooi. 387-90. Louvain: Kritak, 1997.

Wolf, Johann Wilhelm. Wodana. Ghent: Museum voor Nederduitsche Oudheidkunde, 1851.

Worp, J.A. Geschiedenis van het drama en van het tooneel in Nederland. Groningen: Wolters, 1903-7.

Wright, Thomas, ed. Songs and Carols, now first imprinted. London: Percy Society, 1847.

Wright, Thomas, ed. The Seven Sages in English Verse. London: T. Richards, 1845.

Biographical Notes

Ben Parsons - University of Sheffield

c. 5 lines

Bas Jongenelen - Fontys University of Professional Education, Tilburg

c. 5 lines 